\title{
Epizootic shell disease in American lobsters Homarus americanus in southern New England: past, present and future
}

\author{
Kathleen M. Castro' ${ }^{1, *}$, J. Stanley Cobb ${ }^{1}$, Marta Gomez-Chiarri ${ }^{1}$, Michael Tlusty $^{2}$ \\ ${ }^{1}$ University of Rhode Island, Department of Fisheries, Animal and Veterinary Sciences, Kingston, Rhode Island 02881, USA \\ ${ }^{2}$ New England Aquarium, Boston, Massachusetts 02110, USA
}

\begin{abstract}
The emergence of epizootic shell disease in American lobsters Homarus americanus in the southern New England area, USA, has presented many new challenges to understanding the interface between disease and fisheries management. This paper examines past knowledge of shell disease, supplements this with the new knowledge generated through a special New England Lobster Shell Disease Initiative completed in 2011, and suggests how epidemiological tools can be used to elucidate the interactions between fisheries management and disease.
\end{abstract}

KEY WORDS: Epizootic shell disease $\cdot$ Lobster $\cdot$ Epidemiology

Resale or republication not permitted without written consent of the publisher

\section{INTRODUCTION}

The American lobster Homarus americanus (Milne Edwards) is an important component of the ecosystem in southern New England (SNE) and supports a valuable commercial fishery. Near the end of 1996, a new lobster disease, epizootic shell disease (ESD), emerged, affecting lobster in SNE. The disease presented as deep shell lesions along the anterior dorsal carapace, rapidly spreading to all parts of the dorsal surface (Smolowitz et al. 2005). ESD subsequently spread spatially and temporally along the northeast coast of the United States (Castro \& Somers 2012). Errant American lobsters with shell disease were also captured in Norwegian waters (van der Meeren 2008).

The American lobster stock in SNE is now classified as overfished and in larval recruitment failure (ASMFC 2010), and severe management options are being considered that will affect the fishery. While these management strategies are designed to address the problems in the lobster stock, they may also affect the host-pathogen dynamics (Kuris \& Lafferty
1992, Murray 2004). Changes in fishing policy may impact host biomass and disease dynamics. Knowledge about the epizootiology of ESD should be incorporated into management strategies. The need to understand the impact of disease in this new era of emergent marine diseases is of utmost importance.

This paper reviews existing and new knowledge about ESD and suggests that a new emphasis be placed on the interactions between disease and fisheries management.

\section{SHELL DISEASE}

Past

The term 'shell disease' is a general one, used to describe a wide range of erosive lesions, pits and/or discolorations in the cuticle of the exoskeleton of crustaceans (Smolowitz et al. 2005, Cawthorn 2011). Shell disease is common in crustaceans. Generally thought to be caused by chitinoclastic or lipolytic bacteria, it is identified by discolored or eroded exo- 
skeleton resulting in rust disease in red king crabs Paralithodes camtschaticus and Tanner crabs Chionoecetes bairdi, burnt spot disease in the European crab Carcinus maenas, brown spot disease in shrimp Neohelice granulata and just plain 'shell disease' in blue crabs Callinectes sapidus and lobsters Homarus americanus (Sindermann 1990). Typically, the bacteria associated with the lesions are rod-shaped, chitinolytic and gram-negative (Porter et al. 2001). Sindermann (1991) emphasized that shell disease should be more accurately called a 'syndrome' characterized by progressive exoskeletal erosion resulting from activity of chitinoclastic microorganisms, often affecting stressed crustaceans. Syndrome is a general term defined as a collection of signs and symptoms known to frequently appear together but without a known cause. The term 'disease' is more specific and is defined as a disorder in a system or organ that affects the body's function and usually meets at least 2 of these criteria: recognized etiologic agent (cause); identifiable group of signs and symptoms; or consistent anatomic alterations.

Shell disease in Homarus americanus was first described $75 \mathrm{yr}$ ago in lobsters held for extended time periods at high densities in tidal impoundments (Hess 1937). This type of shell disease in lobster is called 'classical' shell disease. Two types of classical shell disease have been described: impoundment disease (ISD) and burn/rust spot disease (BSSD). The early lesions of ISD are bilaterally symmetrical and are centered around setal cores on the dorsum of the animal (Bullis et al. 1988). The disease is seen as melanized brown to black-colored erosions that commence with the removal of epicuticle, extend through the exocuticle and then the calcified endocuticle, and in extreme cases, penetrate the noncalcified endocuticle to the internal tissues (Smolowitz et al. 1992). The blackening or melanization occurs as an inflammatory response and causes crosslinking in the proteins in the layers of the carapace, forming a wall that inhibits invasion by pathogens (Unestam \& Ajaxon 1976, Lightner \& Redman 1977). A common histological characteristic of ISD is a scooped out appearance of the eroded cuticle (Smolowitz et al. 2005). Damage to the exoskeleton is not a prerequisite to shell damage, although it can be a precursor (Stewart 1984). Malloy (1978) was able to experimentally transmit ISD in $H$. americanus after abrasion under laboratory conditions (Getchell 1989). BSSD was first described from lobsters found in polluted areas (Ziskowski et al. 1996). The appearance of the spots both histologically and grossly is consistent with focal trauma to the carapace (Smolowitz et al. 2005) with irregularly shaped lesions attributed to several different fungi (Stewart 1980) and/or bacteria (Rosen 1970, Sindermann 1991).

Enzootic or endemic shell disease (EnSD) has been observed in fished lobsters for many years, but was only recently recognized formally and named. It is characterized by light to moderate 'pitting' of lobster shell (Cobb \& Castro 2006), and in this respect may be an analog of ISD. The number of affected individuals in any wild population has been relatively small, and the relative impact on the affected population assumed to be insignificant. Typically, lobsters in Rhode Island, USA, exhibited minor EnSD signs (monitored during a Rhode Island Department of Environmental Management trawl survey). EnSD gave way, in the 1990s, to a much more aggressive form characterized by extensive, melanized and deep lesions of the carapace. The lesions appeared to start in the dorsal area of the carapace just behind the rostrum and along the midline. This new and aggressive disease was first documented in Rhode Island waters in 1997 (Castro \& Angell 2000), and by 2000 it was classified as an epizootic as it was widely distributed both temporally and spatially (Smolowitz et al. 2005). The appearance of this disease corresponded with record abundance levels for the SNE lobster stock (ASMFC 2009) (Fig. 1).

Fine-scale monitoring data records on ESD in Rhode Island coastal waters from 1994 to present show trends in prevalence, size, and sex (Castro \& Somers 2012). Larger males and females (> $80 \mathrm{~mm}$ carapace length) were the first to show signs of the disease, specifically ovigerous females that retain their shells for longer periods of time. The inshore areas of Narragansett Bay showed the highest prevalence, which was closely aligned with molting periods that occurred in the late spring and early fall (Castro \& Angell 2000, Castro et al. 2006). There were many reports of females with shell disease molting with eggs still attached to the disfigured cast shell (Castro \& Angell 2000).

Initial studies by Chistoserdov et al. (2005) described ESD as a cuticular disease with no obvious implications of immune system failure or systemic problems. Some bacterial communities were identified, but the bacteria present in the lesions were not primarily chitinoclastic. Other organisms apart from bacteria found in the lesions were thought to be secondary invaders. Smolowitz et al. (2005) confirmed that the pathology of the lesions differed from other shell disease types in that pillars of chitin remained while degradation occurred in the other polymers in the carapace. Lobsters with ESD were found to have 


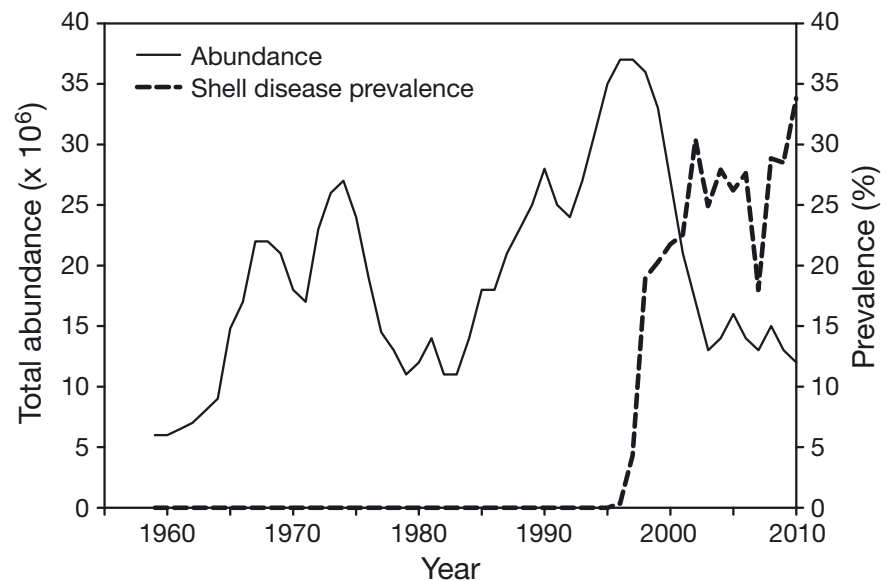

Fig. 1. Homarus americanus. Total abundance of lobster and epizootic shell disease (ESD) prevalence in southern New England, USA. For calculation of abundance see Gibson (2011). ESD prevalence was obtained from a sea sampling survey conducted by the Rhode Island Department of Environmental Management

higher levels of ecdysone (molting hormone) than non-shell-diseased lobsters, indicating the involvement of the endocrine system in the defense strategy (Laufer et al. 2005). The presence of high ecdysone levels in ovigerous females implied a possible disruption in reproductive cycles.

The abundance of lobsters in the SNE area began to decline coincident with a rise in shell disease prevalence (Fig. 1). A corresponding decline in new settlement has also been observed (Fig. 2). The relationship between young-of-the-year and pre-recruit abundance changed dramatically in 1996 (Wahle et al. 2009), weakening the relationship between the stages and indicating an increased rate of mortality.

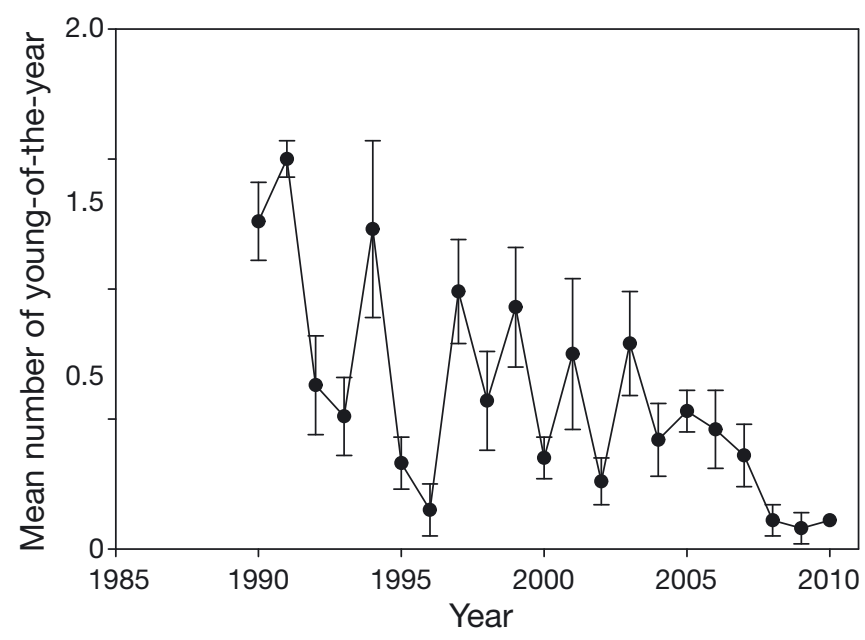

Fig. 2. Homarus americanus. Mean $( \pm \mathrm{SE})$ settlement of young-of-the-year lobster for Rhode Island, USA, from diveroperated suction sampling surveys (R. A. Wahle pers. comm.)
Stevens (2009) also found evidence for increased mortality in the laboratory during molting due to complications of ESD.

ESD appeared to be spatially restricted to the SNE area with occasional reports of low prevalence in the areas south of the Long Island Sound (LIS), deeper offshore areas, the Gulf of Maine and Canadian waters. Temperature was implicated as a factor in ESD, lower temperatures limiting the spread of the bacteria and increasing water temperature, causing physiological stress leading to a more susceptible host (Tlusty et al. 2007). Glenn \& Pugh (2006) showed a significant correlation between disease in Buzzards Bay and a series of warmer than average water temperatures from 1999 to 2003. As temperature also affects growth rates and size at maturity, the interplay between the endocrine system, environmental factors and disease becomes complex. Castro et al. (2006) documented decreases in growth increment associated with shell disease from tagging studies, subsequently demonstrated by Stevens (2009) in the laboratory. Inadequate nutrition was also implicated in a paper by Tlusty et al. (2008), suggesting that lobster health and condition was compromised during chronic feeding of herring. However, Bethoney et al. (2011) examined the nitrogen isotope ratios (specifically the $\delta^{15} \mathrm{~N}$ signature) in lobster tissue based on diet and found no relationship between the $\delta^{15} \mathrm{~N}$ values and ESD on lobsters in the wild, suggesting that food supply is diverse and is not limited in the ESD lobsters.

A large oil spill occurred in January 1996 off the southern coast of Rhode Island; 2700 US tons of No. 2 fuel oil was released during a large winter storm, and large surf dispersed the fuel oil into the water column and bottom sediments. An estimated 9 million lobsters died during the 1996 event (Cobb et al. 1999). There was speculation that the oil spill triggered the shell disease event; oil can directly kill marine organisms, or cause sub-lethal disruption of physiological/ behavioral activities (Moore \& Dwyer 1974, Payne et al. 1983). To date, there is no direct evidence that the oil or its dispersants were responsible for the initiation of ESD.

\section{Present}

As ESD continues to persist in the SNE area with a prevalence ranging from 10 to $40 \%$ depending on the location and year, there has been a concurrent decrease in pre-recruit abundance and landings of this stock. Management measures that previously 
were thought to be effective are not accomplishing their goals, even after 1.2 million mature females were released into the area to offset losses because of the North Cape oil spill (DeAngelis et al. 2010). Funds were secured to support 9 new research projects on shell disease through the NE Lobster Shell Disease Initiative (2006-2011) to obtain new information about the causes and consequences of ESD in wild lobster stocks. Although previous research pointed to limited physiological effects from ESD, the rapid change in lobster abundance changed male: female ratios (observed in Rhode Island state trawl surveys and sea sampling) and reduced young-ofthe-year settlement, combined with changing environmental conditions, suggest that a complex suite of potentially interactive factors, including ESD, are affecting lobster population levels. The research projects were organized around the simple hostpathogen-environment model. Based on what was known about ESD, the basic hypothesis behind the conceptual model states that it is ultimately a compromised internal state of the lobster that allows a pathogen to create a diseased state (Tlusty et al. 2007). Results from these new research projects have changed several of the previous conclusions about ESD.

The complex bacterial community in ESD lesions has now been well characterized through several culture-dependent and -independent methods (Bell et al. 2012, Chistoserdov et al. 2012, Meres et al. 2012). Bacterially produced protein- and cellulosedegrading enzymes are more abundant in diseased shells than on healthy shells, and although chitindegrading enzymes are also abundant, their presence does not differ with health status (Bell et al. 2012). Two bacterial species in particular, Aquimarina 'homaria' and 'Thalassobius' sp., are abundant in lesions in wild ESD lobsters (Chistoserdov et al. 2012). These 2 species are also present on some nondiseased animals, but in lower abundance (Chistoserdov et al. 2012, Meres et al. 2012). Detailed observations on lobsters in the laboratory showed that a lesion is a more advanced state of ESD, and prior to lesion formation, there is activity within the shell that in specific cases, can be observed as a discoloration or tanning of the shell (Tlusty \& Metzler 2012). Quinn et al. (2012) took advantage of this progression to assess changes in bacterial community over the course of disease progression. They also challenged laboratory-reared lobsters by direct exposure to these 2 bacterial species, either alone or together, through placement of bacteria-impregnated filters on abraded areas of the shell, and the resultant lesions suggest that $A$. 'homaria' and 'Thalassobius' sp. are involved in lesion progression (Quinn et al. 2012). Non-abraded lobsters did not show signs of shell disease, implying that a compromised shell may be necessary for the disease to develop. Abraded control lobsters exposed to filters with sterile seawater, however, did develop lesions. The fact that these lesions were heavily colonized by A. 'homaria' and 'Thalassobius' sp. suggests that these bacteria can easily take advantage of a compromised shell to cause and colonize lesions (Quinn et al. 2012). However, these experiments did not exclude the possibility that other bacteria may be involved in lesion initiation and progression in wild lobsters. Several other bacterial genera have been shown to contribute to discrimination between lesioned areas and healthy shell areas collected from the wild and could be involved in the etiology of the disease (Meres et al. 2012). Identification of causative agents for the disease would be facilitated by further challenge experiments following the advance of candidate bacteria in the lesions from the early stages of lesion initiation. Including the work of Quinn et al. (2012), much of the evidence gathered in recent research confirms that ESD is caused by an opportunistic bacterial pathogen or pathogens able to cause lesions only in lobsters with a compromised shell (in this case, a shell that has the epicuticle abraded).

Failures in the integrity and strength of the shell may be a major factor in the initiation of ESD. While changes were not observed at gross scales (Tlusty \& Metzler 2012), Kunkel et al. (2012) described finescale structural and chemical properties of the shell. Interestingly, this work demonstrated that different types of shell disease in lobsters can be differentiated by the nature of the areas of the lobster cuticle that are affected. Lesions in ISD are located at dermal gland canals, while ESD lesions are located on the plane between these canals. A weak exocuticle may contribute to injuries. The strength of the exocuticle is a result of tanning and cross-linking of protein and chitin in the exoskeleton. Work by Laufer et al. (2012) showed that alkylphenols impede the phenoloxidase reactions through their interference with the incorporation of tyrosine into the cuticle, delaying the hardening process.

In addition to the physical protection the shell offers, it also possesses antimicrobial properties. Kunkel et al. (2012) documented that a thin outer calcite layer provides a dense microbial barrier that dissolves slowly through pores in the epicuticle, providing an external alkaline unstirred layer inhibitory to bacterial movement and metabolism. Injury to the epicuti- 
cle covering this mineral cuticle surface unleashes a strong flux of alkalinity, providing a further general immune response accentuating the normal alkalinity of the antimicrobial unstirred layer. Mars (2010) also demonstrated that the shell possesses antimicrobial properties and described a series of peptides that are organic, cationic, heat stable and less than $10 \mathrm{kDa}$. Kunkel et al. (2012) suggests that changes in ocean $\mathrm{pH}$ could affect the proper chemical functioning of the cuticle on its outside surfaces.

Research resulting from the NE Lobster Shell Disease Initiative provided some insights into the impacts of ESD on lobster physiology, immunity and behavior. The expression of several genes changed significantly with disease status. In animals showing signs of ESD, low arginine kinase expression in muscle indicates that lobsters may be energetically compromised. There was an elevated expression of ecdysteroid receptor in both muscle and hepatopancreas of shell-diseased lobsters and increased cytochrome P450 enzymes, indicating that shell disease is associated with disruption of chemical metabolism and hormonal signaling (Tarrant et al. 2012). Homerding et al. (2012) found that lobsters from the eastern portion of LIS had compromised immune systems relative to lobsters from western LIS or from Maine, suggesting that differences in the immune capabilities of lobsters could be a factor in the regional differences in disease prevalence (prevalence is significantly higher in eastern LIS than western LIS or Maine). Lobsters with ESD showed significant differences in plasma antimicrobial activity in plasma and hemocyte phagocytosis, oxidative burst in hemocytes, as well as bacterial load in the hemolymph. Aggression and mating were affected by ESD. In behavioral trials, Rhode Island diseased males lost in paired fights with non-diseased Rhode Island males of equal size. In mate choice experiments, female lobsters were not able to discriminate between a male with shell disease or without (Rycroft et al. 2012); however, mating success is directly associated with dominance status (Atema \& Voigt 1995).

There are a multitude of environmental factors that can act and interact to increase the probability of onset or severity of ESD. Some earlier papers have suggested that temperature limits the spread of shell disease to the north and south and that warmer water temperatures contribute to immune system disruption (Dove et al. 2004, Glenn \& Pugh 2006). Tlusty \& Metzler (2012) examined the effects of temperature on shell disease in lobsters held in an aquarium system and found that the severity and extent of the lesions was higher at $15^{\circ} \mathrm{C}$ than in lobsters main- tained at 10 and $20^{\circ} \mathrm{C}$. Since the upper lethal temperature for lobsters is $30^{\circ} \mathrm{C}$ (van Olst et al. 1980) and Steenbergen et al. (1978) did not observe a decrease in immune system function until lobsters were held at $22^{\circ} \mathrm{C}$ or above, these results suggest that disease progression is not simply explained by a weakening of the lobsters' immune system due to increased temperatures. These results also show that shell disease lesions can develop at a wide range of temperatures $\left(10-20^{\circ} \mathrm{C}\right)$, suggesting that factors other than temperature may be contributing to determining the current distribution range of the disease. Models studying the impact of temperature on shell disease should consider the impact of temperature on lobster physiology (including molting cycle, shell thickness, and growth), as well as the impact of temperature on the growth and expression of virulence factors by the pathogen.

Environmental pollution can negatively impact the health of crustaceans, leading to disease directly through toxicity or indirectly through immune suppression. The high prevalence of several other syndromes, including idiopathic blindness $(50 \%$ prevalence) and necrotizing hepatopancreatitis (15\% prevalence) observed in lobsters from a single site in Rhode Island, suggests some exposure to degraded environmental conditions (Shields et al. 2012). As previously mentioned, alkylphenols can affect the integrity of the shell (Laufer et al. 2012). Doughtie et al. (1983) and Andersen et al. (2000) have associated metals with shell disease in crustaceans. Recent research on the distribution and levels of alkylphenols and heavy metals in the hepatopancreas and other tissues of lobsters from SNE, however, failed to find a clear relationship between heavy metals and selected alkylphenols and ESD (Jacobs et al. 2012, LeBlanc \& Prince 2012). Researchers were not able to measure levels of alkylphenols in lobster shell due to technical challenges (Jacobs et al. 2012). The use of pesticides to control mosquitoes carrying West Nile virus has also come under scrutiny. Pesticides can affect cuticle formation in decapods, and hormone analogs have been found to inhibit chitin synthesis in the blue crab Callinectes sapidus at concentrations of 1 part per billion (Horst \& Walker, 1999). Work by De Guise et al. $(2004,2005)$ verified that methoprene and resmithrin act as immune suppressants on adult lobster, and Walker et al. (2005) found that methoprene caused high mortality rates in postlarval lobsters and that it bioaccumulates in the hepatopancreas, gonad, epithelial tissue, and most significantly, the eyestalk of adults. Methoprene also affected the synthesis and incorporation of chitoproteins into 
adult postmolt shells. More research needs to be done to evaluate the potential relationship between pesticides and other pollutants with ESD. Furthermore, the results of the '100 lobster project' showed the high prevalence of other syndromes and/or diseases (idiopathic blindness, granulomas, and necrotizing hepatopancreatitis), unrelated to ESD, in lobsters from a single site in Rhode Island (Shields et al. 2012) indicate that shell disease should be examined as part of a larger suite of health issues for the American lobster. Research should be carried out to evaluate the prevalence and distribution of these syndromes, as well as the association with environmental pollution. This may require a complex epidemiological study powerful enough to show potential interactions between pollutants and disease (Vethaak \& Rheinallt 1992, Adams 2005).

\section{Future}

It is clear that multiple stressors exist in the environment that could be implicated in the etiology of ESD and that the lobsters in SNE have experienced physiological and endocrine changes that affect their ability to molt, mate, and reproduce, as well as increase their mortality rates and decrease egg production and survival. ESD is an opportunistic disease that does not occur unless the host is compromised (such as by injury, weakness, and/or deficiencies in nutrition). This makes it difficult to predict where and how shell disease will appear using simple correlative techniques. The concurrent emergence of other anomalies unrelated to shell disease (idiopathic eye lesions and necrotizing hepatopancreatitis) implicates both opportunistic invasions and anthropogenic physiological disruptions. The difficulty in finding clear 'causal' agents is not unexpected in a largescale multifactorial ecological investigation. The use of Koch's postulates is limited in investigations where both infectious and non-infectious factors may work in concert. Plowright et al. (2008) suggests that the way forward is to use several strategies including epidemiological criteria, strong inference, model selection, and triangulation to establish causation in disease ecology and aid in developing management strategies. Epidemiological models are important tools that facilitate incorporation of disease dynamics into management strategies. Epidemiology is used to identify the processes that control the invasion and persistence of pathogens and, secondly, to optimize the deployment of control strategies to manage disease outbreaks (Gilligan \& van den Bosch 2008).
These models can be useful tools for generating testable predictions for large-scale and long-term processes. Feehan et al. (2012) recently field-tested a predictive model on disease outbreak following a hurricane in Nova Scotia, Canada, and was able to predict massive mortalities in caged sea urchins by an opportunistic paramoeba, a situation that emulates the 'perfect storm' that occurred prior to the 1999 LIS disaster with American lobster.

With many other emerging marine diseases affecting valuable resources, resource managers are struggling with incorporating disease dynamics into management strategies (Kuris \& Lafferty, 1992, Murray 2004). Many management strategies may directly or indirectly affect disease dynamics, especially if they alter key parameters such as mortality, disease transmission, pathogen survival, and host availability (Sokolow et al. 2009). Dobson \& May (1987) suggested that factoring parasites into fisheries management might shift the optimal choice among management options. Management policies seek to improve long-term sustainability by allowing animals to grow to a size that maximizes yield per recruit or spawning stock biomass. Classic epidemiological theory predicts that for simple diseases, pathogens flourish when the host is abundant. Transmission to new hosts must be greater than the loss of infected hosts by death or recovery for the disease to persist. Models by Dobson \& May (1987) show that it is possible to fish out a parasite in some situations, depending on the parasite, the host, and the mode of transmission. However, if there are multiple hosts or the parasite has an open population, this strategy will not be effective. For example, intensive fishing pressure decreased the age-specific prevalence of the tapeworm Triaenophorus crassus in whitefish Coregounus lavaretus but did not reduce another tapeworm Diphyllobothrium ditremum because of intermediate hosts; T. crassus uses pike as a host, which is also heavily fished, while $D$. ditremum uses birds as hosts, which are readily available (Wood et al. 2010).

Pathogens that affect host mortality have strong potential to exacerbate fishing mortality. The black abalone Haliotis cracherodii in California in the late 1980s started to collapse and declined to $1 \%$ of historical levels. The prevailing hypothesis was that up to 16 stressors acted on this animal, coinciding with a withering foot disease caused by a Rickettsia-like organism. The California Department of Fish and Game elected to close the fishery, hoping that the survivors might be resistant to the disease and provide sufficient broodstock to restore the dwindling population. However, looking further back in the 
history of the black abalone, it has been noted that removal of sea otters, the prime predator of the abalone, caused increased densities of the abalone. These peak host densities provided the single most important precondition for the spread of an infectious disease (Lafferty \& Kuris 1999). This is very similar to the American lobster situation in SNE. ESD appeared at the highest abundance levels ever recorded for the SNE lobster stock. High population densities can facilitate transmission of a disease not easily transmitted through contact by: (1) increasing competition for resources such as habitat and food and therefore stress; (2) increasing the amount of the pathogen that is released into the environment; and/or (3) increasing the likelihood that the host and pathogen will encounter each other. The ecosystem regime shift that occurred during the 1990s in Rhode Island reduced the number of lobster predators, relaxing a top-down control on lobster abundance (Collie et al. 2008, Boudreau \& Worm 2010). As abundance grew, there were observed shifts in habitat, with many lobsters having to reside in soft substrates as opposed to the preferred rocky habitat owing to limited availability. This shift in habitat may have increased host-pathogen encounters or possibly produced stress that enabled the pathogen to take hold. During this time period, many crab species increased in abundance, especially an invasive species, the green crab, which effectively competes with juvenile lobster $(<35 \mathrm{~mm}$ carapace length) for resources (Rossong et al. 2011).

Kuris \& Lafferty (1992) used modeling to evaluate the effects of several management strategies on a hypothetical crustacean fishery that was affected by a parasitic castrator. The results of that modeling exercise illustrated the complex relationship between the interactions of management, recruitment, and parasites that are likely to occur. Strategies to combine fishing activities with the population dynamics of not just the host, but also the pathogen, showed the negative consequences of some of the most common management tools and positive consequences of new strategies such as culling or treating infected individuals. Murray (2004) describes a model that predicts the impact of fishing on pre- and postepidemic systems with several outcomes possible. In some cases, maximizing pre-epidemic harvest may actually increase the survival of the post-epidemic population. The appropriate strategy depends on the biology of both the pathogen and the host. The key to the success of many of these management strategies was to understand the characteristics of the disease survivors and the population dynamics of the parasite and/or pathogen.

The information needed to design a general epidemiological model includes: the distribution of the pathogen and the host, the mode and dynamics of transmission, the presence of reservoirs and carriers, the identity of the intermediate hosts, the potential for development/selection of disease resistance, the impact of the disease on reproduction and mortality of the host, and the influence of environmental factors and ecosystem drivers on disease dynamics and transmission. Although we are missing some crucial information about ESD, a working epidemiological model is proposed in Fig. 3. This model is useful for

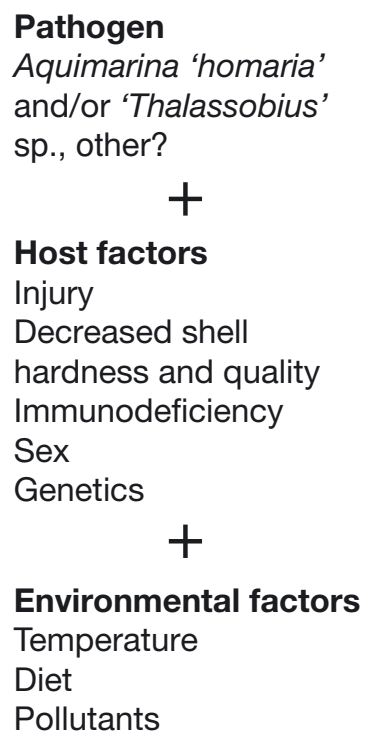

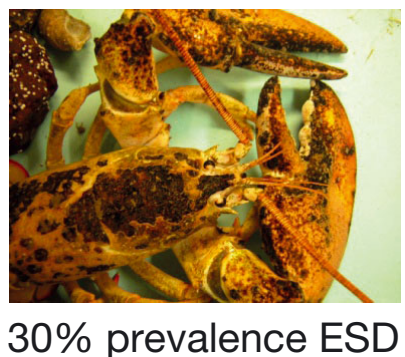

(RI)

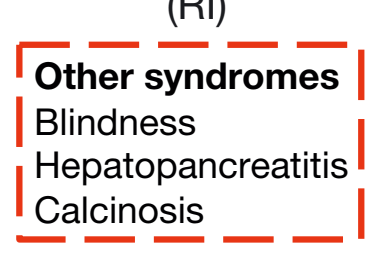

Physiological consequences

- Changes in molting behavior

- Decreased reproduction

- Decreased growth increment

- Susceptibility to systemic infections

Population level consequences

- Recruitment

- Mortality (gender/size)

- Sex ratio

- Decline in spawning stock

Fig. 3. Simple epidemiological model for epizootic shellfish disease (ESD). RI: Rhode Island 
seeing gaps in knowledge and data needs. A basic model starts with an unaffected host (which may or may not be susceptible) and a pathogen. Susceptible lobsters may be weakened as a result of other factors such as injury, temperature, inadequate diet, contaminants, an inappropriate environment, or multiple interacting factors. The pathogen must be present and able to invade and cause damage to the shell, further compromising the basic state of the lobster's health. The rate and mechanism of transmission may shift over time as some susceptible hosts become scarce (such as mature females) and others become susceptible (smaller lobsters and males). Infected lobsters are presumed to show external signs of shell disease and physiological, hormonal, and behavioral changes. These bring about consequences to mortality, growth, and reproduction. Feedback loops will be important mechanisms for the disease dynamics. For example, molting will externally rid the lobster of the ESD signs, but the stress of molting and softened shell state may make the lobster more vulnerable to reinfection.

Several questions have emerged as a result of this model. The susceptibility of the host is a crucial component of the model. We have seen differences in prevalence of ESD by geographic location. Are there genetic differences between populations that could explain the distribution of the disease? Larger and mature lobster shells are more susceptible to damage as molting intervals are longer, but we have now seen higher prevalence in smaller lobsters and males. Does the lobster become compromised after acquiring shell disease, or was the lobster compromised before the shell disease? Similar to the sea urchin example above, did the extremely high population abundance levels contribute to the initiation of the disease, and should they be avoided in the future? Will management strategies to increase the number of what appears to be the most susceptible hosts based on disease prevalence (larger lobsters and mature females) actually help maintain the disease in the population? If high abundance enabled the establishment of ESD, will low host abundance cause its eradication? Can lobsters become resistant to the disease? Can we re-establish a healthy lobster stock by stopping fishing, or is fishing necessary to control the disease? And can we create new management reference points that incorporate disease dynamics?

Several bacterial species have been identified that are consistently part of the bacterial community found in the lesions and can be used to discriminate between healthy and diseased lobsters. Can any of these bacterial candidates cause disease without a compromised shell? Can the available challenge model (Quinn et al. 2012) be improved so that Koch's postulates can be fulfilled? Which are the bacterial species associated with initiating the lesions? Are there other hosts or reservoirs such as green or cancer crabs that may explain persistence of the disease even with low lobster abundance? Can they persist in the environment (sediment or water) without a host? Did the combination of habitat change with increased lobster abundance in the 1990s allow for increased transmission?

The environment is described as changing with subsequent regime shifts and changes in species distribution and abundance. What environmental factors could be influencing the distribution of the disease? Does this indicate some overall level of unsuitability? Is some nutrient missing that is critical to lobster health? Is there a disruptor in the environment that is causing the lobster to become susceptible? Are there multiple causes that are interacting to produce the disruption? What is the significance and impact of other lobster diseases and syndromes on lobster populations in southern New England?

There is an urgent need to further understand the relationship between disease in the marine environment and the fishery. This can only be accomplished utilizing new tools such as epidemiological model development and testing to understand how fishing mortality can be managed in conjunction with natural mortality (from both predators and pathogens).

\section{CONCLUSIONS}

ESD has emerged (among a multitude of other syndromes and diseases) in a changing ecosystem and has rapidly become a major factor affecting lobster health and yields from heavily fished populations. The identification of common pathogens and the gross appearance of the lesions at specific sites on the shell fulfill the criteria for classifying ESD as a disease. Many questions remain about the pathogens, transmission, and causes and consequences of ESD. To fully understand the consequences of management for these stocks, both the host and the pathogen population dynamics need to be considered. Epidemiological models can provide a systembased tool to evaluate the combination of the host and pathogen dynamics and effects of management actions. The application of simple models to our current state of knowledge about ESD in American lobsters yields many questions that need to be field tested and evaluated. 
Acknowledgements. The authors thank the researchers involved in the New England Lobster Shell Disease Initiative for their efforts in working their new information within a unifying hypothesis and setting the stage for moving forward. We thank several anonymous reviewers that made significant contribution to the improvement of this manuscript. This work was supported by the National Marine Fisheries Service as part of the New England Lobster Research Initiative under NOAA grant NA06NMF4720100 to the University of Rhode Island. The views herein are those of the authors and do not necessarily reflect the views of NOAA or any of its subagencies.

\section{LITERATURE CITED}

Adams SM (2005) Assessing cause and effect of multiple stressors on marine systems. Mar Pollut Bull 51:649-657

Andersen LE, Norton JH, Levy NH (2000) A new shell disease in the mud crab Scylla serrata from Port Curtis, Queensland (Australia). Dis Aquat Org 43:233-239

Atema J, Voigt R (1995) Behavior and sensory biology In: Factor JR (ed) Biology of the lobster Homarus americanus. Academic Press, New York, NY, p 313-348

Atlantic States Marine Fisheries Commission (ASMFC) (2009) American lobster stock assessment report for peer review. Report. No. 09-01. Atlantic States Marine Fisheries Commission, Washington, DC

Atlantic States Marine Fisheries Commission (ASMFC) (2010) Recruitment failure in the southern New England lobster stock. Prepared by the American Lobster Technical Committee, available at www.ct.gov/dep/lib/dep/ fishing/commercial/asmfc_american_lobster_technical_ committee_report_stock_recruitment_failure_in_southern_ new_england.pdf

Bell SL, Allam B, McElroy A, Dove A, Taylor GT (2012) Investigation of epizootic shell disease in American lobsters (Homarus americanus) from Long Island Sound: I. Characterization of associated microbial communities. J Shellfish Res 31:473-484

> Bethoney ND, Stokesbury KDE, Stevens BG, Altabet MA (2011) Bait and the susceptibility of American lobsters Homarus americanus to epizootic shell disease. Dis Aquat Org 95:1-8

Boudreau SA, Worm B (2010) Top-down control of lobster in the Gulf of Maine: insights from local ecological knowledge and research surveys. Mar Ecol Prog Ser 403: 181-191

Bullis RL, Leibovitz L, Swanson L, Young R (1988) Bacteriologic investigation of shell disease in deep sea crabs, Geryon quinquedens. Biol Bull 175:304

Castro KM, Angell TE (2000) Prevalence and progression of shell disease in American lobster, Homarus americanus, from Rhode Island waters and the offshore canyons. J Shellfish Res 19:691-700

Castro KM, Somers BA (2012) Observations of epizootic shell disease in American lobster, Homarus americanus, in Southern New England. J Shellfish Res 31:423-430

> Castro KM, Factor JR, Angell T, Landers DF Jr (2006) The conceptual model of shell disease revisited. J Crustac Biol 26:646-660

Cawthorn RJ (2011) Diseases of American lobsters (Homarus americanus): a review. J Invertebr Pathol 106:71-78

Chistoserdov AY, Smolowitz R, Mirasol F, Hsu A (2005) Culture-dependent characterization of the microbial community associated with epizootic shell disease in American lobster, Homarus americanus. J Shellfish Res 24:741-748
Chistoserdov AY, Quinn RA, Gubbala SL, Smolowitz R (2012) Bacterial communities associated with lesions of shell disease in the American lobster (Homarus americanus). J Shellfish Res 31:449-462

Cobb JS, Castro KM (2006) Shell disease in lobsters: a synthesis. Rhode Island Sea Grant, Narragansett, RI

Cobb JS, Clancy M, Wahle RA (1999) Habitat based assessment of lobster abundance: a case study of an oil spill. Am Fish Soc Symp 22:285-298

Collie JS, Wood AD, Jeffries HP (2008) Long term shifts in the species composition of a coastal fish community. Can J Fish Aquat Sci 65:1352-1365

> DeAngelis BM, Cooper R, Clancy M, Cooper C and others (2010) Impacts of V-notching the American lobster. J Shellfish Res 29:489-496

> De Guise S, Maratea J, Perkins C (2004) Malathion immunotoxicity in the American lobster (Homarus americanus) upon experimental exposure. Aquat Toxicol 66:419-425

De Guise S, Maratea J, Chang ES, Perkins C (2005) Resmithrin immunotoxicity and endocrine disrupting effects in the American lobsters (Homarus americanus) upon experimental exposure. J Shellfish Res 24:781-786

- Dobson AP, May RM (1987) The effects of parasites on fish populations - theoretical aspects. Int $\mathrm{J}$ Parasitol 17: 363-370

Doughtie DG, Conklin PJ, Rao KR (1983) Cuticular lesions induced in grass shrimp exposed to hexavalent chromium. J Invertebr Pathol 42:249-258

Dove ADM, LoBue C, Bowser P, Powell M (2004) Excretory calcinosis: a new fatal disease of wild American lobsters Homarus americanus. Dis Aquat Org 58:215-221

Feehan C, Scheibling RE, Lauzon-Guay JS (2012) An outbreak of sea urchin disease associated with a recent hurricane: support for the 'killer storm hypothesis' on a local scale. J Exp Mar Biol Ecol 413:159-168

Getchell RG (1989) Bacterial shell disease in crustaceans: a review. J Shellfish Res 8:1-6

Gibson M (2011) Southern New England lobster stock status and fishery issue paper. Rhode Island Department of Environmental Management, Rhode Island Division of Fish and Wildlife, Marine Fisheries Office, Jamestown, RI

Gilligan CA, van den Bosch F (2008) Epidemiological models and invasion and persistence of pathogens. Annu Rev Phytopathol 46:385-418

Glenn RP, Pugh TL (2006) Epizootic shell disease in American lobster (Homarus americanus) in Massachusetts coastal waters: interactions of temperature, maturity and intermolt duration. J Crustac Biol 26:639-645

Hess E (1937) A shell disease in lobsters (Homarus americanus) caused by chitinivorous bacteria. J Biol 3:358-362

Homerding M, McElroy A, Taylor GT, Dove A, Allam B (2012) Investigation of epizootic shell disease in American lobsters (Homarus americanus) from Long Island Sound: II. Immune parameters in lobsters and relationships to the disease. J Shellfish Res 31:495-504

Horst MN, Walker AN (1999) Effects of the pesticide methoprene on morphogenesis and shell formation in the blue crab, Callinectes sapidus. J Crustac Biol 19:699-707

Jacobs M, Laufer H, Stuart J, Chen M, Pan X (2012) Endocrine disrupting alkylphenols are widespread in the blood of lobsters from southern New England and adjacent offshore areas. J Shellfish Res 31:563-572

Kunkel JG, Nagel W, Jercinovic MJ (2012) Mineral fine structure of the American lobster cuticle. J Shellfish Res 31:515-526

Kuris AM, Lafferty KD (1992) Modeling crustacean fisheries: 
effects of parasites on management strategies. Can J Fish Aquat Sci 49:327-336

Lafferty KD, Kuris AM (1999) How environmental stress affects the impacts of parasites. Limnol Oceanogr 44: 925-931

Laufer H, Demir N, Biggers WJ (2005) Response of the American lobster to the stress of shell disease. J Shellfish Res 24:757-760

Laufer H, Chen M, Johnson M, Demir N, Bobbitt JM (2012) The effect of alkylphenols on lobster shell hardening. J Shellfish Res 31:555-562

LeBlanc LA, Prince D (2012) Metal concentrations in tissues of American lobsters (Homarus americanus) with epizootic shell disease. J Shellfish Res 31:543-554

Lightner DV, Redman R (1977) Histochemical demonstration of melanin in cellular inflammatory processes of penaeid shrimp. J Invertebr Pathol 30:298-302

Malloy SC (1978) Bacteria induced shell disease on lobsters (Homarus americanus). J Wildl Dis 14:2-10

Mars MA (2010) Characterization of antimicrobial activity present in the cuticle of American lobster, Homarus americanus. MS thesis, State University of New York at Stony Brook, Stony Brook, NY

Meres NJ, Ajwzie CC, Sikarood M, Vemulapalli M, Shields JD, Gillevet PM (2012) Dybiosis in epizootic shell disease of the American lobster (Homarus americanus). J Shellfish Res 31:463-472

Moore SF, Dwyer RL (1974) Effects of oil on marine organisms: a critical assessment of published data. Water Res 8:819-827

Murray AG (2004) Managing harvesting to minimize the impact of epidemics on wild fish stocks. Nat Resour Model 17:103-121

> Payne JF, Kiceniuk J, Misra R, Fletcher G, Thompson R (1983) Sublethal effects of petroleum hydrocarbons on adult American lobster (Homarus americanus). Can J Fish Aquat Sci 40:705-717

Plowright RK, Sokolow SH, Gorman ME, Daszak P, Foley JE (2008) Causal inference in disease ecology: investigating ecological drivers of disease emergence. Front Ecol Environ 6:420-429

Porter L, Butler M, Reeves RH (2001) Normal bacterial flora of the spiny lobster Panulirus argus and its possible role in shell disease. Mar Freshw Res 52:1401-1405

Quinn RA, Metzler A, Smolowitz RM, Tlusty M, Chistoserdov AY (2012) Exposures of Homarus americanus shell to three bacteria isolated from naturally occurring epizootic shell disease lesions. J Shellfish Res 31:485-494

Rosen B (1970) Shell disease of aquatic crustaceans In: Snieszo SF (ed) A symposium on diseases of fishes and shellfishes. Special Publication No 5. American Fisheries Society, Washington, DC, p 409-415

Rossong MA, Quijon PA, Williams PJ, Snelgrove PVR (2011) Foraging and shelter behavior of juvenile American lobster (Homarus americanus): the influence of a non-indigenous crab. J Exp Mar Biol Ecol 403: $75-80$

Rycroft N, Radcliffe K, McDonugal E, Halverson J, Gerlach G, Deppermann J, Atema J (2012) No olfactory recognition of shell disease in American lobsters, Homarus americanus. J Shellfish Res 31:527-532

Shields JD, Wheeler KN, Moss JA (2012) Histological assessment of the lobsters (Homarus americanus) in the '100 lobsters' project. J Shellfish Res 31:439-448

Sindermann CJ (1990) Principal diseases of marine fish and shellfish, Vol. 2. Gulf Professional Publishing, Academic Press, San Diego, CA
Sindermann CJ (1991) Shell disease in marine crustaceansa conceptual approach. J Shellfish Res 10:491-494

Smolowitz RM, Bullis RA, Abt DA (1992) Pathologic cuticular changes of winter impoundment shell disease preceding and during intermolt in the American lobster, Homarus americanus. Biol Bull 183:99-112

Smolowitz RM, Chistoserdov AY, Hsu A (2005) A description of the pathology of epizootic shell disease in the American lobster, Homarus americanus H. Milne Edwards 1837. J Shellfish Res 24:749-756

> Sokolow SH, Foley P, Foley JE, Hastings A, Richardson LL (2009) Disease dynamics in marine metapopulations: modeling infectious diseases on coral reefs. J Appl Ecol 46:621-631

Steenbergen JF, Steenbergen SMJ, Schapiro C (1978) Effects of temperature on phagocytosis in Homarus americanus. Aquaculture 14:23-30

Stevens BG (2009) Effects of epizootic shell disease in American lobster Homarus americanus determined using a quantitative disease index. Dis Aquat Org 88:25-34

Stewart JE (1980) Disease. In: Cobb JS, Phillips BF (eds) The biology and management of lobsters, Vol. I. Physiology and behavior. Academic Press, New York, NY, p 301-344

Stewart JE (1984) Lobster diseases. Helgol Meersunters 37: 243-254

Tarrant AM, Franks DG, Verslycke T (2012) Gene expression in American lobster (Homarus americanus) with epizootic shell disease. J Shellfish Res 31:505-514

Tlusty MF, Metzler A (2012) Relationship between temperature and shell disease in laboratory populations of juvenile American lobsters (Homarus americanus). J Shellfish Res 31:533-542

> Tlusty MF, Smolowitz RM, Halvorson HO, DeVito SE (2007) Host susceptibility hypothesis for shell disease in American lobsters. J Aquat Anim Health 19:215-225

> Tlusty MF, Myers A, Metzler A (2008) Short- and long-term dietary effects on disease and mortality in American lobster Homarus americanus. Dis Aquat Org 78:249-253

Unestam T, Ajaxon R (1976) Phenol oxidation in soft cuticle and blood of crayfish compared with that in other arthropods and activation of the phenol oxidases by fungal and other cell walls. J Invertebr Pathol 27:287-295

van der Meeren GI (2008) Shell disease in captive American lobsters caught in Norwegian waters. Lobster Newsl 21: $12-14$

van Olst JC, Carlberg JM, Hughes JT (1980) Aquaculture. In: Cobb JS, Phillips BF (eds) The biology and management of lobsters, Vol. II. Ecology and management. Academic Press, New York, NY, p 333-384

Vethaak AD, Rheinallt T (1992) Fish disease as a monitor for marine pollution: the case of the North Sea. Rev Fish Biol Fish 2:1-32

Wahle RA, Gibson M, Fogarty M (2009) Distinguishing disease impacts from larval supply effects in a lobster fishery collapse. Mar Ecol Prog Ser 376:185-192

Walker AN, Bush P, Wilson T, Chang ES, Miller T, Horst MN (2005) Metabolic effects of acute exposure to methoprene in the American lobster, Homarus americanus. J Shellfish Res 24:787-794

Wood CL, Lafferty KD, Micheli F (2010) Fishing out marine parasites? Impacts of fishing on rates of parasitism in the ocean. Ecol Lett 13:761-775

Ziskowski J, Spallone R, Kapareiko D, Robohm R, Calabrese A, Pereira J (1996) Shell disease in American lobster in the offshore Northwest-Atlantic region around the 106mile sewage-sludge disposal site. J Mar Environ Eng 3: $247-27$

Submitted: February 2, 2012; Accepted: July 12, 2012

Proofs received from author(s): August 16, 2012 